\title{
RAIRO-RO
}

\section{Section : «Applications et études de cas»}

Revue française d'automatique, d'informatique et de recherche opérationnelle. Recherche opérationnelle, tome 23, n 1 (1989), p. 97-98.

<http://www.numdam.org/item?id=RO_1989_23_1_97_0>

(C) AFCET, 1989, tous droits réservés.

L'accès aux archives de la revue « Revue française d'automatique, d'informatique et de recherche opérationnelle. Recherche opérationnelle » implique l'accord avec les conditions générales d'utilisation (http://www.numdam.org/ legal.php). Toute utilisation commerciale ou impression systématique est constitutive d'une infraction pénale. Toute copie ou impression de ce fichier doit contenir la présente mention de copyright.

\section{Numdam}

Article numérisé dans le cadre du programme

Numérisation de documents anciens mathématiques

http://www.numdam.org/ 


\section{SECTION : "APPLICATIONS ET ÉTUDES DE CAS »}

Nous ouvrons aujourd'hui dans notre Revue une nouvelle section, intitulée "Applications et Études de cas ». Elle diffère de la section générale en ce que l'originalité de la théorie ou des résultats n'est pas le point principal, si bien même qu'un article de cette nouvelle section pourrait n'en comporter aucun. L'accent sera mis sur l'aspect empirique du problème et sur l'intérêt pratique de l'étude, ainsi que sur les points qui auront assuré son succès. En d'autres termes, au lieu d'études théoriques intéressantes pour la Recherche, suivies parfois d'un exemple illustratif, nous comptons accueillir dans notre nouvelle section des Cas Concrets, traités avec des moyens (Recherche Opérationnelle, Informatique, etc.) qui ne sont pas nécessairement originaux. Le problème concret et son environnement, les moyens utilisés, devront être clairement décrits, et l'apport de l'étude (par rapport à la situation antérieure) nettement établi, et même chiffré. Notre ambition ici serait que les articles de cette section soient beaucoup plus cités dans les Entreprises (et les Écoles de Commerce ou d'Ingénieur) que dans les Revues savantes.

Nous espérons ainsi mieux servir la Communauté de la Recherche Opérationnelle, en offrant aux praticiens un moyen d'expression et de diffusion de leur expérience. Nous espérons même qu'un dialogue pourrait s'établir, dont les meilleures parties pourraient même être publiées dans des numéros ultérieurs.

We open today in our Journal a new Section, entitled "Applications and Case Studies". This Section differs from the general section in that originality of the theory and results is not the main point, with the result that, in the limit, there might not be any. The emphasis will be the empirical aspect of the problem and on the practical implications of the study, and on the points that will have made it successful. In other words, instead of the research oriented theorical studies, sometimes illustrated witch a pedagogical example, we intend to greet in our new section Case Studies, dealed with means (Operations Research, Computer Science, Information Processing, 
etc.) which are not necessarily original. The concrete case and its surroundings, the tools have been used, should be clearly described, and the benefit of the study (with respect to the former situation) neatly stated, and even estimated with figures. Our ambition here would be that the articles of this section be cited more in Companies and Business (or Engineering) Schools than in learned Journals.

Thus we hope to better serve the Operations Research Communauty, by offering the practicioners a mean for expressing and spreading their expertise. We even wish that a dialogue be established, the better parts of it to be published in subsequent issues of our Journal. 